conditions, cause the disease in a mouse model.

A team led by Jeffrey Bluestone of the University of California, San Francisco, studied regulatory $\mathrm{T}\left(\mathrm{T}_{\mathrm{reg}}\right)$ cells in a mouse model of an autoimmune disease in which the body attacks its own nerve tissue.

$\mathrm{T}_{\text {reg }}$ cells expressing the Foxp 3 gene normally act to suppress these harmful immune attacks. However, during the inflammatory response, a subset of the $T_{\text {reg }}$ cells expressed lower levels of Foxp 3 and higher levels of proteins called cytokines.

These unstable $\mathrm{T}_{\text {reg }}$ cells were predominantly present in the antigen-specific $\mathrm{T}_{\text {reg }}$ compartment and induced anti-self immune reactions when transplanted into other mice. However, treating the $\mathrm{T}_{\text {reg }}$ cells with the antiinflammatory cytokine interleukin 2 restored the cells' protective abilities.

Immunity 39, 949-962 (2013)

\section{ARCHAEOLOGY}

\section{Teeth nibble away at invasion theory}

Human remains from a fifth-century cemetery in Oxfordshire, UK, contradict the standard view of the AngloSaxon conquest of Britain.

Historical accounts suggest that Germanic invaders wiped out and replaced local populations at around that time. A team led by Susan Hughes of the Naval Facilities and Engineering Command Northwest in Silverdale, Washington, studied strontium and oxygen isotopes in teeth from the remains of 19 people. This can reveal whether a person ate and drank local foodstuffs.

Just one of the 19 samples contained isotopes indicating that the person came from continental Europe. The others were longtime locals, supporting the idea that Anglo-Saxons merged gradually into the region. J. Arch. Sci. http://doi.org/p4j (2013)

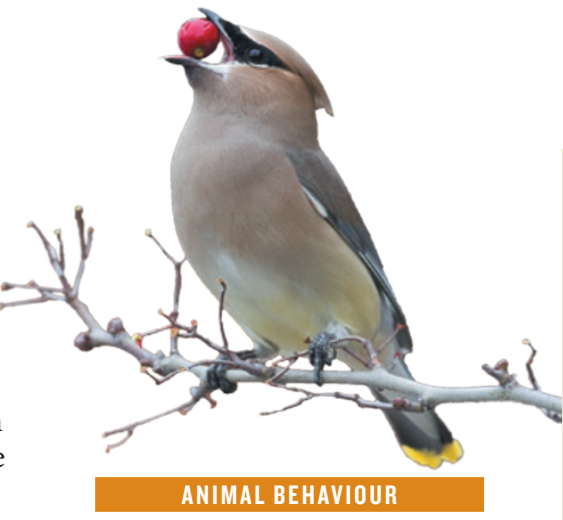

Phantom road frightens birds

Why did the bird not cross the road? Noise, it seems, forms at least part of the explanation.

Christopher McClure, Jesse

Barber and their colleagues at Boise State University in Idaho created a 'phantom road' to test the effects of traffic noise without any actual cars or disruptions in the visual landscape.

The authors played continuous traffic sounds through speakers spaced evenly along a 0.5 -kilometre ridge for four days, followed by four days of silence. They monitored multiple sites along the fake road and in a control area every morning for 7.5 weeks.

When recordings played, the number of birds along the road declined by more than one-quarter. Two species, the cedar waxwing (Bombycilla cedrorum; pictured) and yellow warbler (Setophaga petechia), avoided the noisy road almost completely.

Proc. R. Soc. B 280, 20132290 (2013)

\section{EVOLUTION}

\section{Fish babies bigger in toxic waters}

Live-bearing fish in sulphurrich springs give birth to fewer, larger young than counterparts in non-toxic waters.

Rüdiger Riesch at the University of Sheffield, UK, and his colleagues studied nine species of fish, including the guppy (Poecilia reticulata), which have independently flourished in sulphur springs in the United States, the Caribbean and South America.

The researchers show that

\title{
Wheat not to blame for coeliac rise
}

\section{HIGHLY READ \\ on pubs.acs.org 14 Oct-13 Nov}

The increase in cases of coeliac disease over the past 50 years or so cannot be pinned on the increasing gluten content of wheat, according to an analysis of varieties of the crop going back to the 1920 s.

Some researchers have pegged the rise in the disease - an immune response to the wheat protein gluten - to modern varieties of wheat bred to contain more protein. Donald Kasarda of the Western Regional Research Center in Albany, California, compiled data on the amount of protein in US wheat crops over the past century.

Although Kasarda's analysis showed that the protein level in wheat remained largely unchanged, he did find that people now consume more wheat and foods containing gluten as an additive. This, he suggests, could account for the increase in coeliac disease since the mid-twentieth century.

J. Agric. Food Chem. 61, 1155-1159 (2013)

the toxic waters do not directly damage fish fertility. Instead, parents have fewer offspring as an inevitable trade-off of investing their energy in producing larger offspring, which can more easily detoxify hydrogen sulphide gas.

The discovery illustrates a widespread pattern of predictable evolution, they say. Ecol. Lett. http://doi.org/p5h (2013)

\section{ZOOLOGY \\ Sex messes with a sea slug's head}

A tiny sea slug found on Australia’s Great Barrier Reef stabs its sexual partners through the head with a specialized probe, apparently to inject secretions that influence its partners' behaviour after mating.

Rolanda Lange of Monash University in Melbourne, Australia, and her colleagues observed 16 matings between 20 individuals of a newly discovered sea slug (Siphopteron sp.) that has a two-part penis. In all cases, seconds after the animal had inserted its penile bulb into a sexual partner to transfer sperm, it stabbed the other part - a specialized needlelike structure (pictured) into the head of its mate.

Related sea-slug species are known to inject prostate secretions in a similar manner, but not to the head. The authors suggest that this species is targeting the neural ganglia near the injection site, and that the secretions manipulate the behaviour of the sperm receiver.

Proc. R. Soc. B http://doi.org/ p33 (2013)

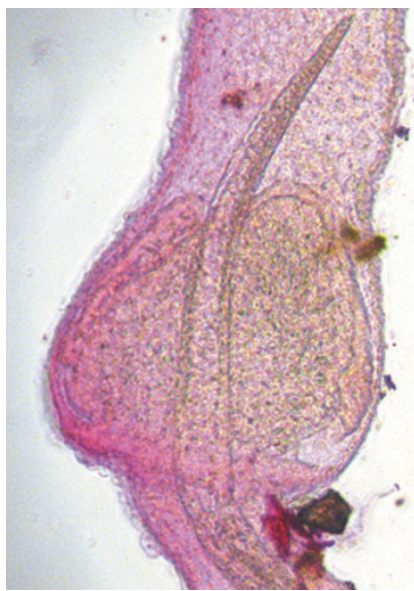

$\rightarrow$ NATURE.COM

For the latest research published by Naturevisit:

www.nature.com/latestresearch 